$\underline{\text { Original Articles }}$

\title{
Risk factors for hospital acquired bloodstream infections in neonatal intensive care unit of B.P. Koirala Institute of Health Sciences, Nepal
}

\author{
*Sunil Kumar Yadav ${ }^{1}$, Shankar Prasad Yadav ${ }^{1}$, Nisha Keshary Bhatta ${ }^{1}$, Piush Kanodia ${ }^{1}$, Rupa Rajbhandari \\ Singh $^{1}$, Basudha Khanal ${ }^{1}$
}

Sri Lanka Journal of Child Health, 2017; 46(1): 16-22

\begin{abstract}
Introduction: With the development of advanced technologies in neonatal intensive care worldwide, survival rates of newborns, particularly low birth weight and premature babies are higher. This has led to longer duration of hospital stay predisposing these babies to hospital-acquired infections (HAIs). Hence it is one of the main cause of morbidity and mortality in the neonatal intensive care unit (NICU).
\end{abstract}

Objective: To determine the risk factors for HAI in NICU of B.P. Koirala Institute of Health Sciences (BPKIHS), Nepal

Method: A prospective cohort study was conducted in a seven bedded teaching and referral NICU. All neonates in NICU who did not have any sign of infection at admission and remained hospitalized for at least 48 hours were observed. HAI was diagnosed according to the $\mathrm{CDC}$ criteria. Risk factors for HAI were analyzed with Chi-square test and Logistic regression model. A $p$-value of $<0.05$ was considered significant.

Results: The incidence rate and density of HAI were $47 \%$ and 39.3 infections per 1000 patient-days respectively. Blood stream infection (BSI) was observed as the most common form of HAI $(60.2 \%)$. Low birth weight and mechanical ventilation were found to be related to hospital acquired infection ( $p$ $<0.05$ ). Staphylococcus aureus was the most commonly isolated agent in haemocultures of patients with BSI.

\section{${ }^{1}$ B.P. Koirala Institute of Health Sciences, Nepal \\ *Correspondence: dr.sunil_yadav@yahoo.com}

(Received on 23 December 2015: Accepted after revision on 17 March 2016)

The authors declare that there are no conflicts of interest

Personal funding was used for this project.

Open Access Article published under the Creative Commons Attribution CC-BY (C) (P) License.
Conclusions: Low birth weight and mechanical ventilation were the most important risk factors for HAI in NICU of BPKIHS, Nepal

DOI: http://dx.doi.org/10.4038/sljch.v46i1.8236

(Key words: Hospital acquired infection, neonatal intensive care unit, risk factors)

\section{Introduction}

Hospital-acquired infections (HAIs) or nosocomial infections (NIs) is a global health problem ${ }^{1}$, and contributes to significant morbidity and mortality, longer hospitalization and increased cost of treatment in both developed and resource-poor countries ${ }^{2}$. NI is defined by the US Department of Health and Human Services for Disease Control and Prevention as an infection occurring during hospitalization which was not present or incubating at the time of admission ${ }^{3}$. Organisms causing most NIs usually emanate from the patient's own body or from contact with hospital staff, contaminated devices and consumables or from the hospital environment ${ }^{4}$. The reported incidence of nosocomial sepsis in neonates from India ranges from $1.5 \%$ to $37 \%{ }^{1-4}$. In contrast, surveillance reports from the USA have reported a rate of $0.9 \%$ to $7 \%{ }^{5}$. A recent review from the World Health Organisation found that the prevalence of health-care-associated infection was 15.5 per 100 patients in developing countries, which was much higher than the prevalence reported from Europe and USA ${ }^{6}$. A study conducted by Shrestha et al in Nepal reported an incidence of nosocomial sepsis of $10.8 \% 7$. The incidence in neonates from India ranges from $1.5 \%$ to $37 \%^{8-11}$. Nevertheless, NIs remain a major cause of preventable morbidity and mortality in developing countries where infection rates are relatively higher due to poor infection control practices, lack of supervision, inappropriate use of limited resources and overcrowding of hospitals ${ }^{2}$.

There are various risk factors for HAI. Prematurity, low birth weight, intrauterine growth retardation, low Apgar score, application of mechanical ventilation and exposure to central venous catheter are the risk 
factors for $\mathrm{NI}^{12}$. According to published articles, the infection rate in neonatal intensive care units (NICUs) of Nepal varied from 7-11.6\% ${ }^{13-15}$. However, risk factors, such as prematurity, low birth weight, length of hospitalization, application of gastric tube and ventilation associated with the NI in NICU in Nepal are rarely reviewed and analysed as most studies only discussed the epidemiological profile of NI in NICU ${ }^{14-18}$.

\section{Objective}

To determine the risk factors for HAI in NICU of B.P. Koirala Institute of Health Sciences (BPKIHS), Nepal

\section{Method}

A prospective cohort study was conducted in a seven bedded NICU of BPKIHS over a one year period from September 2014 to September 2015. BPKIHS is a teaching hospital and tertiary care referral centre in the Eastern part of Nepal. All patients admitted to the NICU without any sign of infection, who remained hospitalized for at least 48 hours during the study period, were eligible for inclusion. Neonates who died or were discharged or were transferred to other departments within 48 hours after admission to NICU, outborn neonates and neonates with severe congenital malformations were excluded from study.

Written informed consent in the local language was taken from the parents and/or guardians of all patients before commencement of study. After admission to NICU, the details were prospectively collected and recorded on a standardized form until discharge from the hospital or death. Hospital born neonates transferred to NICU after birth and available in the unit for at least 48 hours comprised the cohort for infection surveillance which was carried out over a period of one year. All neonates included in the cohort were closely monitored during their hospital stay for clinical signs of infection. For each patient, data on birth weight, adequacy for gestational age, gender, Apgar score at five minutes, absolute neutrophil count, micro-erythrocyte sedimentation rate, C-reactive protein, immature to total neutrophil ratio, blood cultures, lumbar puncture, X-ray of chest, medical devices used (central venous catheter, umbilical catheter, percutaneous catheter, mechanical ventilation), other relevant medical conditions and length of stay were collected. HAI was defined as an infection not present and without evidence of incubation at the time of hospitalization and it was diagnosed according to the CDC criteria ${ }^{19}$. The diagnosis of infection was based on clinical symptoms, laboratory findings and positive blood cultures. In all suspected cases, blood cultures were taken. When needed, urine and tracheal aspirate cultures were added. Lumbar puncture and CSF culture were performed in all patients who had bacterial growth in blood culture or clinical signs of meningitis. HAI was considered to be present if onset of infection was beyond 48 hours of life with either (a) culture of sterile body fluids (blood, CSF, urine) yielding a recognized bacterial pathogen; (b) a tracheal aspirate culture yielding a pure growth of known bacterial pathogens in a neonate on ventilatory support with respiratory deterioration and radiographic pneumonia, or (c) clinical examination revealing a soft tissue infection. Neonates who had clinical features suggestive of infection appearing after 48 hours of birth but not yielding bacterial pathogens on culture of body fluids or tracheal aspirate were defined as having NI if they had a positive sepsis screen. All neonates suspected to have sepsis and meningitis were screened by National Neonatology Forum Guidelines, India ${ }^{20}$.

Infection surveillance was consistently conducted according to the National Infection Surveillance System (NNIS/CDC/Atlanta) definitions ${ }^{19}$, which consider all neonatal infections, whether acquired during delivery or hospitalization, as nosocomial, unless evidence indicates transplacental acquisition. A BSI was defined as isolation of at least one positive peripheral blood culture (except coagulase negative staphylococcus, for which isolation of two positive blood cultures were required) with clinical signs and symptoms. BSIs were broadly divided into two types, laboratory confirmed bloodstream infections (LBSI) and clinical sepsis (CSEP). BSI were considered as clinical sepsis when clinical and laboratory findings of infection were present, without positive cultures, and as laboratory confirmed when positive cultures were also present. The incidence rate of HAI was calculated as number of infections per 100 patients admitted, and incidence density as number of infections per 1000 patient-days.

Descriptive statistics were performed for all studied variables. Some were then categorized according to frequency analysis. Chi-square test was performed for the association between potential risk factors and HAIs. The variables with $p<0.20$ in the univariate analyses were included in multivariate logistic regression model in order to identify independent risk factors for HAI. The level of statistical significance adopted was $p<0.05$. SPSS for Windows 20.0 software was used for all statistical analyses. This study was approved by the Institutional Ethics Review Board (IERB) of BPKIHS. 


\section{Results}

A total of 225 patients was admitted to NICU during the one year period. Sixty patients were excluded from the study (10 died, 46 were transferred to nursery or neonatal ward within 48 hours and 4 were outborn). Fifty four infants developed 78 HAI episodes and 42 infants developed 47 episodes of BSI. Total length of hospital stay in NICU was 1980 days. Incidence rate and incidence density were $47 \%$ and 39 infections per 1000 patient-days respectively. The mean overall BSI rate was 23.7:1000 days. The localisation of neonatal HAI is shown in Table 1.

Table 1

Localisation of neonatal hospital acquired infection

\begin{tabular}{|c|c|}
\hline Localisation & Number (\%) \\
\hline Bloodstream infection & $47(60.2)$ \\
With positive cultures & $14(17.9)$ \\
Clinical sepsis & $33(42.3)$ \\
\hline Meningitis & $16(20.5)$ \\
\hline Pneumonia & $15(19.2)$ \\
\hline Total & $78(100.0)$ \\
\hline
\end{tabular}

The aetiologic agents isolated from blood cultures in laboratory confirmed BSI are shown in Table 2.

Table 2

Aetiologic agents isolated from blood cultures in laboratory confirmed bloodstream infection

\begin{tabular}{|l|c|}
\hline \multicolumn{1}{|c|}{ Microorganism } & Number (\%) \\
\hline Staphylococcus aureus & $08(4.8)$ \\
\hline Klebsiella pneuminiae & $02(1.2)$ \\
\hline Pseudomonas aeruginosa & $01(0.6)$ \\
\hline Enterococcus species & $01(0.6)$ \\
\hline E. coli & $01(0.6)$ \\
\hline Enterobacter & $01(0.6)$ \\
\hline No growth & $151(91.5)$ \\
\hline \multicolumn{1}{|c|}{ Total } & $165(100.0)$ \\
\hline
\end{tabular}

The antibiotic sensitivities of the isolated microorganisms are shown in Table 3. Most of the organisms were sensitive to ciprofloxacin.

Table 3

Antibiotic sensitivity of isolated microorganisms

\begin{tabular}{|c|c|}
\hline Micro-organisms & Sensitive to \\
\hline Staphylococcus aureus & $\begin{array}{l}\text { Ciprofloxacin, } \\
\text { Cefotaxime, } \\
\text { Azithromycin, } \\
\text { Vancomycin, Amikacin, } \\
\text { Gentamycin }\end{array}$ \\
\hline Klebsiella pneumoniae & $\begin{array}{l}\text { Ciprofloxacin, } \\
\text { Levofloxacin, } \\
\text { Meropenem, Amikacin, } \\
\text { Gentamycin, Imipenem }\end{array}$ \\
\hline $\begin{array}{l}\text { Pseudomonas } \\
\text { aeruginosa }\end{array}$ & $\begin{array}{l}\text { Ciprofloxacin, } \\
\text { Ofloxacin, Cefotaxime, } \\
\text { Ceftazidime, } \\
\text { Gentamycin, Imipenem, } \\
\text { Piperacillin, Tobramycin }\end{array}$ \\
\hline Enterococcus species & Vancomycin \\
\hline E. coli & $\begin{array}{l}\text { Ciprofloxacin, } \\
\text { Amikacin, Imipenem }\end{array}$ \\
\hline Enterobacter & $\begin{array}{l}\text { Ciprofloxacin, } \\
\text { Amikacin, Imipenem }\end{array}$ \\
\hline
\end{tabular}

The variables associated with HAI according to the univariate analysis were: birth weight $(\mathrm{p}<0.001)$, Apgar at 5 minutes $(\mathrm{p}=0.023)$ and mechanical ventilation $(p<0.001)$. The variable (umbilical catheterization), although not statistically significant $(p=0.187)$, was included in the multivariate analysis $(p<0.20)$. The multivariate analysis identified two independent risk factors for HAIs in the NICU: birth weight 1501-2500gm ( $<<0.001$; OR $0.183 ; 95 \%$ CI $0.071-0.469)$ and mechanical ventilation $(\mathrm{p}<0.001$; OR 84; 95\% CI 8.899-792.925) [Table 4]. 
Risk factors for hospital acquired bloodstream infections.... Sri Lanka Journal of Child Health, 2017; 46(1): 16-22

Table4: Potential risk factors for hospital acquired infection (HAI) among 165 patients admitted in NICU in univariate (crude) and multivariate model (adjusted)

\begin{tabular}{|c|c|c|c|c|c|}
\hline Variable & $\begin{array}{c}\text { HAI }- \\
n=111(67.3 \%)\end{array}$ & $\begin{array}{c}\text { HAI }+ \\
n=54(32.7 \%) \\
\end{array}$ & $P$-value & $\begin{array}{c}\text { Adjusted OR } \\
(95 \% \mathrm{CI}) \\
\end{array}$ & $P$-value \\
\hline $\begin{array}{l}\text { Gender } \\
\text { Male } \\
\text { Female }\end{array}$ & $\begin{array}{l}59(53.2 \%) \\
52(46.8 \%)\end{array}$ & $\begin{array}{l}25(46.3 \%) \\
29(53.7 \%)\end{array}$ & 0.408 & & \\
\hline $\begin{array}{l}\text { Length of hospitalization } \\
\leq 5 \text { days } \\
6-15 \text { days } \\
\geq 16 \text { days }\end{array}$ & $\begin{array}{l}12(10.8 \%) \\
78(70.3 \%) \\
21(18.9 \%)\end{array}$ & $\begin{array}{l}07(13.0 \%) \\
37(68.5 \%) \\
10(18.5 \%)\end{array}$ & 0.921 & & \\
\hline $\begin{array}{l}\text { Gestational age } \\
\quad>38 \text { weeks } \\
\text { 32-37weeks } \\
\quad<32 \text { weeks }\end{array}$ & $\begin{array}{l}50(45.0 \%) \\
46(41.4 \%) \\
15(13.5 \%)\end{array}$ & $\begin{array}{l}20(37.0 \%) \\
22(40.7 \%) \\
12(22.2 \%)\end{array}$ & 0.327 & & \\
\hline $\begin{array}{l}\text { Birth weight } \\
\quad>2500 \mathrm{~g} \\
\quad 1501-2500 \mathrm{~g} \\
\leq 1500 \mathrm{~g}\end{array}$ & $\begin{array}{l}42(37.8 \%) \\
53(47.7 \%) \\
16(14.4 \%)\end{array}$ & $\begin{array}{l}16(29.6 \%) \\
13(24.1 \%) \\
25(46.3 \%)\end{array}$ & $<0.001$ & $\begin{array}{l}0.031(0.003-0.388) \\
0.183(0.071-0.469)\end{array}$ & $\begin{array}{l}<0.05 \\
<0.001\end{array}$ \\
\hline $\begin{array}{l}\text { Apgar at } 5 \text { minutes } \\
\quad \geq 7 \\
\leq 6\end{array}$ & $\begin{array}{l}60(54.1 \%) \\
51(45.9 \%) \\
\end{array}$ & $\begin{array}{l}19(35.2 \%) \\
35(64.8 \%) \\
\end{array}$ & 0.023 & & \\
\hline $\begin{array}{l}\text { Mode of delivery } \\
\text { Vaginal } \\
\text { Caesarean }\end{array}$ & $\begin{array}{l}49(44.1 \%) \\
62(55.9 \%)\end{array}$ & $\begin{array}{l}20(37.0 \%) \\
34(63.0 \%)\end{array}$ & 0.385 & & \\
\hline $\begin{array}{l}\text { Mechanical ventilation } \\
\text { Yes } \\
\text { No }\end{array}$ & $\begin{array}{c}07(6.3 \%) \\
104(93.7 \%)\end{array}$ & $\begin{array}{l}15(27.8 \%) \\
39(72.2 \%)\end{array}$ & $<0.001$ & 84 (8.899-792.925) & $<0.001$ \\
\hline $\begin{array}{l}\text { Umbilical catheterization } \\
\text { Yes } \\
\text { No }\end{array}$ & $\begin{array}{l}02(01.8 \%) \\
109(98.2 \%)\end{array}$ & $\begin{array}{l}03(05.6 \%) \\
51(94.4 \%)\end{array}$ & 0.187 & & \\
\hline
\end{tabular}

\section{Discussion}

HAI is a significant cause of morbidity and mortality among hospitalized newborns especially in NICUs ${ }^{21}$. However, there is a wide variation in reported infection rates, possibly due to differences in surveillance or study methods. This study adopted the NNIS definitions to overcome this problem. Around the world, each NICU has unique characteristics reflected in the epidemiology of HAIs. It is important to control the inherent aspects of each NICU and make it available to the local laboratory and to the scientific community interested in epidemiological data. Unfortunately, this practice is not universal, and there few published studies portray the epidemiology and risk factors for HAI in Nepalese NICUs.

In this study, incidence rate and incidence density of HAI were $47 \%$ and 39 infections per 1000 patientdays respectively. The mean overall BSI rate was 23.7:1000 patient-days. Incidence of HAI varied from 6.2 to 50.7 infections per 100 admissions, and from 4.8 to 62 infections per 1000 patient days at various centres in previous studies ${ }^{22-25}$. A study by Edison Nagata et al in Brazil reported a similar incidence of $\mathrm{HAI}^{26}$.

BSI was the most prevalent infection in this study, with clinical sepsis accounting for the majority of cases, and nosocomial meningitis was the second most prevalent. This distribution is similar to that reported by other authors ${ }^{27-30}$, although different from some Brazilian reports ${ }^{21,31}$, which describe pneumonia as the most common neonatal HAI. The proportion of BSIs in this study $(60.2 \%)$ is definitely worrisome, since neonatal sepsis carries a particular increased mortality, prolonged length of hospital stay and slower growth among very low birth weight infants and our rates are higher than those usually observed $27,28,29,32$. 
Birth weight, mechanical ventilation and Apgar at 5 minutes were associated with HAI in the univariate analysis but multivariate analysis identified birth weight (1501-2500gm) and mechanical ventilation as independent risk factors for HAI in NICU. Birth weight has been consistently considered as a strong and independent predictor of adverse outcomes, including $\mathrm{HAIs}^{21,27,31,33}$. In this study, the odds ratio of infants whose birth weights were 1501-2500g was $0.183(0.071-0.469)$ which is in accordance with previously published data ${ }^{33}$. Those newborns whose birth weights were $\leq 1500 \mathrm{~g}$ are often more severely ill, the majority of them die before the HAI is documented or even before it really happens. This may explain the apparent paradox of the statistical result. It also underlines the limited ability of our NICU in changing the outcome of these extremely low birth weight newborns.

It is well known that devices are part of the advances in medical therapy that have resulted in significant improvement in neonatal survival. On the other hand, it is well recognized that these same beneficial tools can also place the newborn at a considerable higher risk of health-care associated infections $s^{21,27,31,33}$. In this study, the exposure to mechanical ventilation independently increased the risk for neonatal HAIs.

Umbilical catheterization was observed to be the most important risk factor for the development of HAI in various studies ${ }^{34-37}$. Yet, we observed that mechanical ventilation had the highest calculated risk for developing HAI. Umbilical catheterization was found to be the least risky intervention. This difference may be attributed to the sterile practices during catheter insertion, the microenvironment or colonization of NICU and the infant, presence of comorbidities and duration of catheter use but especially to our principle of early shifting from umbilical catheter to percutaneous catheter whenever possible and assigning a well-educated and experienced team which is responsible for insertion and optimal care of the catheter.

\section{Conclusions}

Low birth weight and mechanical ventilation were the most important risk factors for HAI in NICU of B.P. Koirala Institute of Health Sciences, Nepal.

\section{References}

1. Tikhomirov E. WHO Programme for the control of hospital infections. Chemotherapia 1987; 6(3):148-51.
2. Haley RW, Culver DH, White JW et al. The efficacy of infection surveillance and control programs in preventing nosocomial infections in US hospitals. American Journal of Epidemiology 1985; 121: 182205.

PMid: 4014115

3. Lopez Sastre JB, Coto CD, Fernandez CB. Neonatal sepsis of nosocomial origin: an epidemiological study from the "Grupo de Hospitales Castrillo". Journal of Perinatal Medicine 2002; 30:149-57. http://dx.doi.org/10.1515/JPM.2002.019

PMid: 12012636

4. Emori GT, Gaynes RP. An overview of nosocomial infections including the role of the microbiology laboratory. Clinical Microbiology Reviews 1993; 6:428-42. PMid: 8269394 PMCid: PMC358296

5. Martone WJ, Jarvis WR, Culver DH, Haley RW. Incidence and nature of endemic and epidemic nosocomial infections. In: Bennett JV, Brachman PS (eds) Hospital Infections,3rd ed. Little, Brown and Co, Boston.1992;577-96.

6. Allegranzi B, Nejad SB, Combescure C, Graafmans W, Attar H, Donaldson L, et al. Burden of endemic health-care-associated infection in developing countries: systematic review and meta-analysis. The Lancet 2011; 377(9761):228-41. http://dx.doi.org/10.1016/S01406736(10)61 458-4

7. Shrestha S, Shrestha NC, Dongol Singh S, Shrestha RPB, Kayestha S, Shrestha M et.al. Bacterial isolates and its antibiotic susceptibility pattern in NICU. Kathmandu University Medical Journal 2013; 41(1):6670.

8. Gupta P, Murali MV, Faridi MMA, et al. Clinical profile of Klebsiella septicaemia in neonates. Indian Journal of Pediatrics 1993; 60: $565-72$.

http://dx.doi.org/10.1007/BF02751435

PMid: 8262593 
9. Mandal GP, Raghavan M, Vishnu Bhat B, Srinivasan S. Neonatal septicaemia among inborn and outborn babies in referral hospital. Indian Journal of Pediatrics 1991; 58: 529-33.

http://dx.doi.org/10.1007/BF02750936

10. Sharma PP, Haider D, Dutta A K et al. Bacteriological profile of neonatal septicaemia. Indian Pediatrics 1987; 24:1011-7.

PMid: 3450639

11. Singh M. Nosocomial bacterial infection amongst newborn babies. Indian Journal of Pediatrics 1978; 45: 314-8.

http://dx.doi.org/10.1007/BF02749259

PMid: 750477

12. Clark R, Powers R, White R, Bloom B, Sanchez P, Benjamin DK, Jr. Nosocomial infection in the NICU: a medical complication or unavoidable problem? Journal of Perinatology 2004; 24(6):382-8. http://dx.doi.org/10.1038/sj.jp.7211120

PMid: 15116140

13. Huang YF, Zhuang Siqi, Chen Dongmei, et al. Analysis of nosocomial Infection in NICU and prophylactic strategy. Guangdong Medical Journal 2004; 25(3):260-2.

14. Zhou Yaling ZZ, Geng Qizhi. Clinical analysis of 222 cases of neonates with nosocomial infection. Chinese Journal of Practical Pediatrics 2000; 15(12):743-4.

15. Epidemiological investigation of nosocomial infections in NICU and neonatal bacterial colonization characteristics and variation [database on the Internet]. Peking Union Medical College. 2007.

16. Zhang $\mathrm{Su}$ WL. Analysis of the risk factors causing nosocomial infection in premature infants and its preventive strategy. Acta Universitatis Medicinalis Anhui 2011; 46(6):595-7.

17. Aiyu L. Study on relationship between invasive procedure and nosocomial infection in intensive care unit Clinical Medicine 2006; 26(6):18-9.
18. Zhang Mingzhi ZB. The analysis on pathogen and susceptible factors in infants with mechanical ventilation-associated lower respiratory tract infection. Chinese Journal of Practical Pediatrics 2001; 16(9):546-8.

19. Garner JS, Jarvis WR, Emori TG, et al. CDC definitions for nosocomial infections. American Journal of Infection Control 1988; 16:128-40.

http://dx.doi.org/10.1016/01966553(88)9005 $3-3$

20. National Neonatology Forum, India; Evidence Based Clinical Practice Guidelines, October 2010.

21. Kawagoe JY, Segre CAM, Pereira CR, et al. Risk factors for nosocomial infections in critically ill newborns: A 5-year prospective cohort study. American Journal of Infection Control 2001; 29:109-14. http://dx.doi.org/10.1067/mic.2001.114162 PMid: 11287879

22. Brito DV, de Brito CS, Resende DS, Moreira do OJ, Abdallah VO and Gontijo Filho PP. Nosocomial infections in a Brazilian neonatal intensive care unit: a 4year surveillance study. Rev Soc Bras Med Trop 2010; 43:633-7. http://dx.doi.org/10.1590/S00378682201000 0600006

PMid: 21181013

23. Tian LY, Hamvas A. Risk factors for nosocomial bloodstream infections in a neonatal intensive care unit. Zhongguo Dang Dai Er Ke Za Zhi 2010; 12:622-4.

PMid: 20704794

24. Auriti C, Ronchetti MP, Pezzotti P, Marrocco G, Quondamcarlo A, Seganti G, et al. Determinants of nosocomial infection in 6 neonatal intensive care units: an Italian multicenter prospective cohort study. Infection Control and Hospital Epidemiology 2010; 31:926-33. http://dx.doi.org/10.1086/655461

PMid: 20645863 
25. Sarvikivi E, Karki T, Lyytikainen O. Repeated prevalence surveys of healthcareassociated infections in Finnish neonatal intensive care units. Journal of Hospital Infection 2010; 76:156-60.

http://dx.doi.org/10.1016/j.jhin.2010.03.020

PMid: 20579770

26. Nagata E, Brito ASJ, Matsuo T. Nosocomial infections in a neonatal intensive care unit: Incidence and risk factors. American Journal of Infection Control 2002; 30(1):2631.

http://dx.doi.org/10.1016/j.jhin.2010.03.020

PMid: 20579770

27. Pessoa-Silva C.L., Richtmann R., Calil R., et al. Health care associated infections among neonates in Brazil. Infection Control and Hospital Epidemiology 2004; 25:772-7. http://dx.doi.org/10.1086/502475

PMid: 15484803

28. Auriti C., Maccalini A., Di Liso G., et al. Risk factors for nosocomial infections in a neonatal intensive-care unit. Journal of Hospital Infection 2003; 53:25-30. http://dx.doi.org/10.1053/jhin.2002.1341

PMid: 12495682

29. Urrea M, Pons $M$, Serra $M$, et al. Prospective incidence study of nosocomial infections in a pediatric intensive care unit. Pediatric Infectious Disease Journal 2003; 22:490-3.

http://dx.doi.org/10.1097/000064542003060

00-00002

PMid: 12799503

30. Urrea M., Iriondo M., Thio M., et al. A prospective incidence study of nosocomial infections in a neonatal care unit. American Journal of Infection Control 2003; 31: 505 7.

http://dx.doi.org/10.1016/S01966553(03)00

$077-4$

31. Nagata E., Brito A.S.J., Matsuo T. Nosocomial infections in a neonatal intensive care unit: Incidence and risk factors. American Journal of Infection Control 2002; 30: 26-31. http://dx.doi.org/10.1067/mic.2002.119823

PMid: 11852413

32. Zaidi AKM, Huskins WC, Thaver D, et al. Hospital-acquired neonatal infections in developing countries. Lancet 2005; 365: 1175-88.

http://dx.doi.org/10.1016/S01406736(05)71

$881-\mathrm{X}$

33. Brady MT. Health care-associated infections in the neonatal intensive care unit. American Journal of Infection Control 2005; 33: 26875.

http://dx.doi.org/10.1016/j.ajic.2004.11.006

PMid: 15947743

34. Gaynes RP, Edwards JR, Jarvis WR, Culver DH, Tolson JS, Martone WJ. Nosocomial infections among neonates in high-risk nurseries in the United States. National Nosocomial Infections Surveillance System. Pediatrics 1996; 98:357-61.

PMid: 8784356

35. Pessoa-Silva CL, Richtmann R, Calil R, Santos RM, Costa ML, Frota AC, et al. Healthcare-associated infections among neonates in Brazil. Infection Control and Hospital Epidemiology 2004; 25:772-7.

http://dx.doi.org/10.1086/502475

PMid: 15484803

36. Perlman SE, Saiman L, Larson EL. Risk factors for late onset health care-associated bloodstream infections in patients in neonatal intensive care units. American Journal of Infection Control 2007; 35:17782.

http://dx.doi.org/10.1016/j.ajic.2006.01.002

PMid: 17433941 PMCid: PMC2094724

37. Babazono A, Kitajima H, Nishimaki S, Nakamura T, Shiga S, Hayakawa M, et al. Risk factors for nosocomial infection in the neonatal intensive care unit by the Japanese Nosocomial Infection Surveillance (JANIS). Acta Med Okayama 2008; 62:261-8. PMid: 18766209 